\title{
REVALUATION OF WROCŁAW PUBLIC USE BUILDINGS IN YEARS 2005 - 2013
}

\author{
Paweł KIRSCHKE \\ Wrocław University of Technology \\ Faculty of Architecture, Wrocław, Poland
}

\begin{abstract}
In the years 2005-2013 in Wroclaw, there was commissioned to use hundreds of public buildings, including fifty revalued monuments These were: offices, museums, theatres, science and education facilities, as well as commercial buildings: banks, department stores, office buildings and hotels. The success of these projects was the merit of Wroclaw scientists who nurtured these outstanding works of architecture and convince the public to the fact that they stand for works which cannot be missed. The merit of architects and conservators was professionally prepared projects and effective supervision of investment, making the implementation of technical and program objectives not colliding with protection of historic material of the objects.
\end{abstract}

Keywords: restoration, buildings of public use, commercial buildings, Wroclaw

\section{INTRODUCTION}

In Wroclaw, in the years 2005-2013 were put into use nearly three hundred utilities. This was the result of building momentum lasted for twenty years in Poland, called prosperity stimulated by activities to promote the city as a good place to do business, a thriving centre of learning and culture, and a great tourist attraction. The catalysts of this phenomenon were: success of series of major commercial projects in the turn of the twenty and twenty-first century, the organization of Euro 2012, combined with the city's infrastructure

\footnotetext{
${ }^{1}$ Corresponding author: Wrocław University of Technology, Faculty of Architecture, Bolesław Prus street, 50-317 Wrocław, Poland, e-mail: pawel.kirschke@ pwr.wroc.pl, tel.+48713206265,
} 
modernization step, and the prospect of the existence of Wrocław as European Capital of Culture in 2016. A key element of these changes was to revalue fifty historic public buildings, which, thanks to the work of architects and conservators of Wrocław regained its lights and significantly helped to maintain centre-art role and unique atmosphere of the Old Town.

\section{ORIGINS OF RESTORATION OF WROCŁAW PUBLIC BUILDINGS}

Wrocław always appeared as a unique town, whose prosperity and culture materialized in created art and architecture. Over the centuries following the political changes meant that the city was in the range of different countries: Poland, Czech Republic, Austria, Prussia, the German Empire, the German Reich and again Poland. Not only did the rulers change but also the citizens exchanged. Newcomers and future generations had to use from the legacies of different cultures, but at the same time they could not cut off from their own roots. Every time this resulted in the need for self-determination, in order to create a hierarchy of values to guide all the goals and aspirations. To enrich the achievements of earlier cultures respect was necessary and the will to continue, which was particularly important and visible in the architecture. The fact that in Wroclaw in the ongoing process of creation public facilities historical objects play an important role, has its roots not only in the history but also in the fact that in the late nineteenth and early twentieth century Wroclaw, the capital of the rich province, was equipped with wonderful buildings of public offices, museums, theatres, scientific facilities, as well as hundreds of commercial buildings: banks, department stores, office buildings and hotels. [8] All of them are now in a huge pool of buildings, which (after being assigned the appropriate program) can successfully continue to fulfil its mission, both the utilitarian and symbolic. Today revalorization of these buildings would not have been possible if it had not been for research conducted for years on these objects and the struggle for their appreciation ${ }^{2}$. These activities had made the public demand for public facilities in Wroclaw was associated with a feeling that the creation of new values in architecture is particularly spectacular when at the same time we appreciate the achievements of former generations. Such reasoning - natural in places where the continuity of culture was maintained - after World War II in Wroclaw was not obvious. Ruination of the city, population exchange, dematerialisation of all institutions and companies and political control of

\footnotetext{
${ }^{2}$ The results of this research were popularized in numerous exhibitions, conferences, publications. See. $[1,3,4]$
} 
reconstruction process, for fifty years shattered relationship with the past. Only now, through years of efforts, and the next, the successful conclusion of restoration of flagship public buildings, the sense of such a bond returns. An excellent, timeless architecture of neostylish, Art Nouveau and modernist buildings, so different from the modern "temples of commerce" and the glass office buildings remains the pride of the centre of Wroclaw. In the districts of the nineteenth century and in the periphery, concentrations of services and urban accents often arise in the rebuilt post industrial objects for public facilities.

\section{REVALORIZATION AND RENOVATION OF WROCŁAW PUBLIC BUILDINGS}

The restoration analysis carried out in recent years on Wroclaw public buildings shows that the actions taken against their methods and their effectiveness were sometimes very different. Crucial were: the purpose and scale of the reconstruction, and the degree of change in use. The biggest problems were created by reconstructions of objects whose primary function, such as industrial, was replaced by service. This required a radical adaptation work, increased costs and resulted in huge losses in the historic building substance. Relatively minor complications arose in the case of revaluation of objects that since the beginning had the function of public use, especially those that had arisen in the twentieth century, in an era when used technical solutions were not that much different from today. The realization of investments and sources of financing were also essentially different depending on the type of building: different for objects related to culture, science and administration, and different for commercial buildings.

\subsection{Revalorization of culture and science objects}

The main factor influencing the regeneration strategy of cultural and science objects are its social property letting long-term and comprehensive investment planning, which defines the method of obtaining finance coming from municipal funds or central. In this period crucial was the fact that (while maintaining adequate procedures), these investments could be supported by substantial, reaching up to $70 \%$, European subsidies ${ }^{3}$.

The most interesting example of comprehensive measures for restoration of cultural objects was revitalization of Old Podwale in Wroclaw. It was initiated

\footnotetext{
3 The way of selecting designers and contractors is also a specific, which is made
} obligatory in the competitions, which are usually a big attraction for architects. 
in 2002 by developing conservation study, which guidelines were used to perform two Local Spatial Development Plans. The primary objective of the project was the restoration of the urban character of the Liberty Square. This had been achieved by erecting a giant building of the National Forum of Music and the creation of the plate, on the square, that will serve mass and cultural events. The task of restoration were the revalorization of: Opera, City Museum (in the former Palace of the Kings of Prussia), Pokoyhof and the Hotel Monopol. At the nearby Theatre Square, one revalorized Puppet Theatre and Media Library, and along the Świdnicka, Krupnicza and Kazimierz Wielki streets, one was able to carry out renovations almost all of its commercial buildings and townhouses ${ }^{4}$.

Extensive works were also carried out in the northern part of the Old Town, where dominate historical objects related to higher education. Here was restored Main Building of the University of Wroclaw, which along with University Church and the new building of the Faculty of Law has created a great framework of University Square. Grandeur also regained complex of historic buildings Ossolineum (housed in a former monastery of the Crusaders with the Red Star) and the Philology Faculty of Warsaw University (in the former convent of the Norbertines). At the same time were carried out renewals of all the objects around Nankier Square (and the surface of the square), and revitalization of alleys and gardens that are in the area. After the completion of the ongoing restructuring of the boulevards and historic wharves of the Oder, described region, linked closely with attractions of Ostrów Tumski, will become not only a place saturated with centre-forming public buildings, but also, thanks to beauty of revalued monuments and urban spaces, a favourite meeting place for locals and a remarkable tourist attraction.

Long-term activities involving the renewal of the objects of general interest were carried out also in the area of Centennial Hall and the Zoological Garden. This was done in accordance with the developed by the City Hallstrategic plan of creation in Wroclaw second service centre of culture and entertainment with a rank comparable to the centre in Old Town. The work has been preceded in 2006 by an entry of the Centennial Hall complex on the UNESCO World Heritage Site. It secured the objects and their environment from hasty reconstructions and facilitated the acquisition of European funds ${ }^{5}$. Since 2009

\footnotetext{
${ }^{4}$ The complexity of the work shows that these processes were accompanied by transformation of Świdnicka Street and Theatre Square into walking passages as well as the revitalization of the baroque garden at the Royal Palace and the Promenade along with the Old Town Square Garden.

${ }^{5}$ From the European Regional Development Fund under the Operational Programme Innovative Economy. There was a total of 100 million zł, thanks to which, between
} 
the revitalization of Four Dome Pavilion to the Museum of Contemporary Art (a branch of the National Museum) has lasted. In the vicinity of the complex, one was able to create additional attractions: a multimedia fountain at the Pergola and Afrykarium, at the Zoo. In 2012 began a revitalization of the neighbouring modern WUWA team.

In the analyzed period, one also made some interesting adaptation of historic buildings for cultural purposes. These included: the Museum of "Pan Tadeusz" in the converted baroque building Market 6 and the Museum of Contemporary Art in raid shelter by Legnica Street. Synagogue under the White Stork was renewed, so that, apart for its basic function, it could also serve as a concert hall and theatre. The most spectacular project was the reconstruction and development of the Musical Theatre Capitol at Jozef Pilsudski street ${ }^{6}$.

Also, historic buildings belonging to the university underwent remodelling or at least renovations. This was the case of already mentioned buildings of the University of Wrocław. Wrocław University of Technology also took care of its historic buildings - built in the early twentieth century for the Technische Hohschule. Their renovations were connected with the construction of several new objects, including the Library of Science and Technology and the Student Cultural Centre, so that after sixty years, it was finally complete to create the campus of the university ${ }^{7}$. A different revaluation strategy was adopted for the team of Clinic of Medical Academy. Due to the lack of space, one decided to leave here only didactic functions that are able to "move" historic buildings, and a new complex of Clinics was built in Krzyki. Somewhat less success was with renewing lower level schools, which after all are also included in the magnificent buildings designed by Richard Plüddemann and Wrocław modernists.

2008-2014 one managed to renovate the structure, remodel audience and lobbies, and restoration of facades that recovered the original gold color. Adjacent to Centennial Hall catering pavilion was rebuilt and extended to the Regional Centre of Business Tourism. For ease of operation, one modernized communication system and created a multi-level underground parking. [http://halastulecia.pl/projekty-unijne]

6 Capitol restoration project made in 2009 by KKM Kozień Architects studio. Implementation was completed in 2013. The cost of the investment was 114 million $\mathrm{zł}$. It has to be pointed out that revalorization of the Synagogue under the White Stork and the Capitol received in 2010 and 2013 Lower Silesia Laurel of Conservator.

7 These meticulous renewals, unfortunately, contrast with adverse changes made in the University buildings designed in the 60s of twentieth century by Professor Tadeusz Brzoza and Marian Barski, which not being protected as historical monuments were rebuilt in a way that blurs their architectural values. 


\subsection{Restoration of the commercial buildings while maintaining functions}

The catalyst of erecting commercial buildings and the main objective of such investments was, is and will be profit. This also concerns, unfortunately, revalorization of historic buildings, which limits the possibility of such projects to those that after the modernization works promise hope for smooth operation and loans refund. This typically creates an enormous pressure from the owners for the modernization of the object which is a great threat to the substance of the monument. Therefore, in the case of this type of investment it is necessary to ensure a harmonious collaboration of architects and conservators with the owner $[6,7]$.

In Wrocław survived more than a hundred historic department stores, banks, office buildings and hotels. The main advantage of these objects is their excellent location in the centre, where the density and compatibility of services ensure successful conducting of commercial activities. Positive are also susceptible to the building structure modernization processes. Their magnificent architecture, in practice, is unfortunately often the burden, because for the owners the costs associated with its maintenance are difficult to accept. Therefore, in any case, the key is the selection of the program and to investment in order to balance it financially, to make the owner was convinced that the unique architecture can not only be a source of commercial success but also a reason for pride . $^{8}$

The flagship project in this area was the reconstruction and development of the department store Renoma made in 2006-2009 on the basis of the Design Studio Maćków [6, 9]. Auspicious effects were also made by revitalization of three historic commercial buildings on the Rzeźnicza street, reconstruction of Niepold Passage and Pokoyhof, and renovations of several Art Nouveau and modernistic department stores by the Market and streets: Świdnicka, Oławska and Ruska .

Revaluation also underwent several historic office buildings, including the Town Office at Nowy Targ, and in Krzyki: Revenue Office and headquarter of EnergiaPro (formerly Mining Office). Interesting results were also obtained in

\footnotetext{
${ }^{8}$ In the future, it may appear that the impact on the purpose of revalorization, which will press the location, is absolutely a priority. It is seen in the direction of the changes taking place in countries such as France, Germany and the Netherlands, where localization of an object in the wrong area is one hundred percent failure [10].

${ }^{9}$ The author of the article described the projects in several publications, namely: $[4,6,7]$
} 
the rebuilding of hotels: Monopol, Polonia, Piast and Granary (in the fourteenth-century granary). ${ }^{10}$

\subsection{Reconstruction combined with the change in the mode of use}

Action within objects having useful function since the dawn is fairly neutral. Much more difficult are those in which the original function, for example industrial, requires radical adaptation work, which involves not only the cost but also the inevitable loss of historical substance. These types of projects used to be associated with major reconstructions and extensions, which greatly raised their cost. So the key is the selection of program objectives, technical and functional, so as not to conflict with the protection of historic buildings substances $[6,7]$.

In Wrocław worked out various investments in which coming from different eras: railway stations, factories, shelters or hydropower plants were adapted to the public interest. This was, for example, the case of the Times office or Wrocław Business Park 3 located in buildings of former factory PZL Hydral. A huge success was carried out in 2009-2014 restoration of the historic complex of the Main Railway Station ${ }^{11}$. It became not only a modern railway station but also the great service object, so that it contributed to the revival of the whole district. It already became an impulse to rise in the neighbourhood large commercial objects and to renovate nearby hotels.

\section{CONCLUSIONS}

Of the hundreds of service historic buildings preserved in Wrocław, in recent years fifty have been restorated, and more than a few dozen overwent more or less professional renovations. Successful revalorization of Centennial Hall, Synagogue under the White Stork, Renoma and the Central Station showed what opportunities lie in the historic public buildings. The success of these activities is due to the efforts of scientists from Wrocław and the work of architects and conservators, who were able to prepare professional projects and supervise the construction effectively.

Not every investor, however, can afford investing money reaching the million Euros and therefore urgent action is to develop a system of actions that will

\footnotetext{
${ }^{10}$ The construction of new hotels and renovation of historical objects of this type are due to an increase of attractiveness of the city as a centre of science, business and tourism in Wrocław. Crucial importance is also a chance for the existence of the city in 2016 as the European Capital of Culture and scheduled for 2017 World Games.

${ }^{11}$ Revaluation was done on the basis of the office projects by Group 5 Architects [11].
} 
save uninhabited houses reaching into disrepair. As can be seen from the observation of the author, it is not at all certain that such measures are taken. Large shopping centres and offices locate almost exclusively in the new complexes, which are being currently erected in Wrocław. Nor is there and you will not be the need to locate large banks in magnificent historic buildings, such as the New Stock Exchange or the former headquarter of the Reichsbank at the Wolność street. One cannot also see people willing to renew such excellent facilities as: Lions Cinema or the Hatzwelds Palace. Historic hotels turning into ruin: Grand at Pilsudski street and Savoy by Kościuszko Square. With such investments key is to find any functional program making a chance of meaningful performance and financial success, rational when it comes to the cost of rebuilding and not ruining the historic structure.

\section{REFERENCES}

1. Architektura Wrocławia, t. 4, Gmach, redaktor J. Rozpędowski, Wrocław, Oficyna Wydawnicza Politechniki Wrocławskiej, 1998.

2. http://halastulecia.pl/projekty-unijne/

3. Hochhäuser für Breslau 1919-1932, redaktor J. Ilkosz, B. Störtkuhl, Aschenbeck \& Holstein Verlag, Delmenhorst 1997.

4. Kirschke P.: Rewitalizacja historycznego centrum Wroctawia, w: Deklinacja odnowy miast: z dyskusji nad rewitalizacją w Polsce, redaktor K. Derejski [i in.]. Poznań, Wydawnictwo Naukowe Wydziału Nauk Społecznych Uniwersytetu im. Adama Mickiewicza, 2012, 153-167.

5. Kirschke K., Kirschke P.: Studium historyczno-urbanistycznokonserwatorskie wraz $z$ wytycznymi konserwatorskimi dla zespotu urbanistycznego Stare Podwale, w Obrębie Stare Miasto we Wroctawiu. Maszynopis w archiwum Biura Rozwoju Wrocławia. Wrocław 2002

6. Kirschke K., Kirschke P.: Wartościowanie $w$ decyzjach architektonicznych na przykładzie rewitalizacji wrocławskich obiektów użyteczności publicznej, w: Wartościowanie zabytków architektury, redaktor B. Szmygin, Warszawa, ICOMOS 2013, 100-111.

7. Kirschke P.: Wrocławskie zabytkowe obiekty komercyjne, których funkcja przestała się sprawdzać, w: Wartość funkcji w obiektach zabytkowych, redaktor B. Szmygin, Warszawa, ICOMOS 2014, 137-154.

8. Leksykon architektury Wrocławia, redaktor R. Eysymontt [i in.], Wydawnictwo Via Nova, Wrocław 2011.

9. Maćków Z. Piątek G.: Dom towarowy Renoma we Wroctawiu, Architektura Murator, 178,79, (2009), 32-43. 
10. No Excuse: Re-use!, Faculty of Architecture and the Built Environment Delft 2014.

11. Zelent R. Kirschke K. Kirschke P. [i in.].: Dworzec główny PKP we Wroctawiu, Architektura Murator, 216, 9, (2012), 38-60.

\section{REWALORYZACJA WROCŁAWSKICH BUDYNKÓW UŻYTECZNOŚCI PUBLICZNEJ W LATACH 2005-2013}

\section{Streszczenie}

W latach 2005-2013 we Wrocławiu oddano do użytku kilkaset obiektów użyteczności publicznej, w tym pięćdziesiąt zrewaloryzowanych obiektów zabytkowych: urzędów, muzeów, teatrów, obiektów nauki i szkolnictwa, a także budynków komercyjnych: banków, domów handlowych, biurowców i hoteli. Katalizatorami tych zdarzeń były: zakończone sukcesem wielkie inwestycje komercyjne przeprowadzone na przełomie XX i XXI w., organizacja Euro 2012, a także perspektywa zaistnienia Wrocławia jako Europejskiej Stolicy Kultury. Procesu tego nie udałoby się przeprowadzić bez działań grupy naukowców i urzędników miejskich, którzy po dwudziestu latach starań doprowadzili do tego, że zapotrzebowanie społeczne na obiekty użyteczności publicznej powiazzane zostało we Wrocławiu z poczuciem, że tworzenie nowych wartości $\mathrm{w}$ architekturze jest szczególnie spektakularne, gdy równocześnie doceniamy dorobek dawnych pokoleń. Z kolei zasługą wrocławskich architektów i konserwatorów było profesjonalne przygotowanie projektów tych przebudów i skuteczny nadzór nad inwestycjami, dzięki czemu chęć realizacji celów programowych, technicznych i użytkowych nie stała w sprzeczności z ochroną zabytkowej substancji obiektów.

Słowa kluczowe: rewaloryzacja, obiekty użyteczności publicznej, budynki komercyjne, Wrocław

Editor received the manuscript: 28.12 .2014 
